\title{
THE HISTORY OF THE DEVELOPMENT OF THE NATURAL ENVIRONMENT IN THE KOKORITSA MICROREGION (BELARUS)
}

DOI: https://doi.org/10.18509/GBP210101t

UDC: 502.11:550.822.02(476)

\author{
Dmitry Tsvirko ${ }^{1,3}$ \\ Tomasz Kalicki ${ }^{1}$ \\ Yury Trifonov ${ }^{2}$ \\ ${ }^{1}$ Jan Kochanowski University in Kielce, Institute of Geography and \\ Environmental Sciences, Poland \\ ${ }^{2}$ Belarusian State University, Faculty of Geography and Geoinformatics, Belarus \\ ${ }^{3}$ The National Academy of Sciences of Belarus, Institute of History, Belarus
}

\begin{abstract}
The history of the development of the natural environment of the Kokoritsa microregion and its relationship with humans in prehistory were studied. Kokoritsa microregion is a group of archaeological sites located at a close distance from each other within the territory of the Sporovsky Biological Reserve (western Belarus). The most active excavations were carried out on the territory of the archaeological site "Kakoryca-4" (mostly Neolithic and Bronze Age finds). The paper presents mainly the results of field paleogeographic research in 2020. Based on radiocarbon and spore-pollen analyses, some data were obtained indicating early agricultural activities of prehistoric people.
\end{abstract}

Keywords: Kokoritsa microregion, paleogeography, Holocene, peat bog deposits.

\section{INTRODUCTION}

Kokoritsa microregion is a group of archaeological sites situated at a close distance from each other on sandy elevations in the basin of the Yaselda River (Pripyat tributary) and Lake Sporovskoye on the territory of the Belarusian Polesie (Fig. 1).

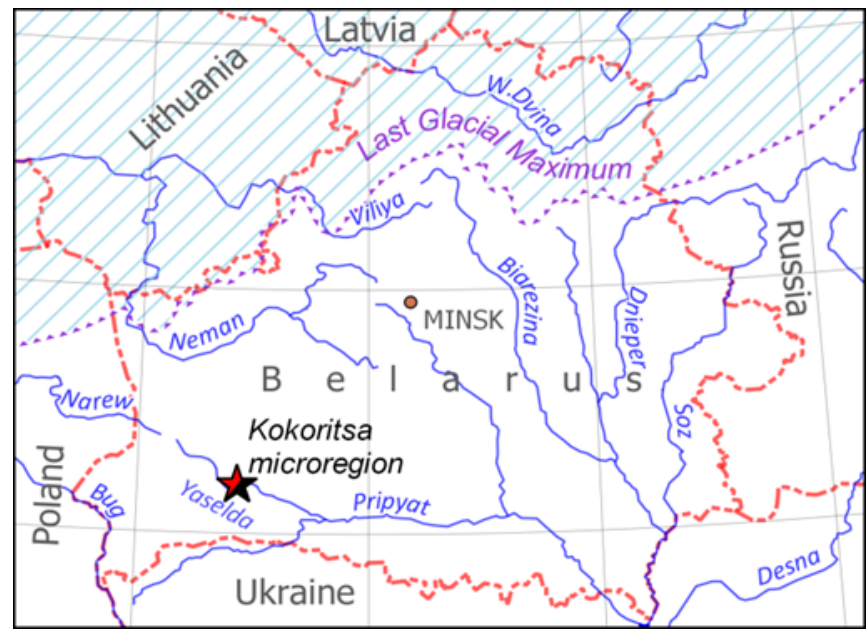

Figure 1. Location of the Kokoritsa microregion and the border of the LGM

In 2020, during the expedition, new field data were obtained, which complement the already published materials on the Kokoritsa microregion about the development of the natural environment over the last 11,700 calendar years (Holocene period) [1, 2]. Lake 
Sporovskoye was much larger during the Preboreal (PB) and Boreal (BO). At that time (PB-BO), carbonate deposits were accumulating in it. At the turn of the Boreal and the Atlantic, there was an intensification of the processes of bog formation and a decrease in the size of Lake Sporovskoye [1]. Earlier, we also made some assumptions about the dynamics of the Yaselda riverbed throughout time [2,3]. We presume that in the middle and the end of the Atlantic period (approx. from 7000 14C yr BP to $560014 \mathrm{C} \mathrm{yr} \mathrm{BP),} \mathrm{the}$ Yaselda riverbed was closer to the Sporovo II site, which led to the accumulation of silty peats due to floods (as the close location of the riverbed facilitated the delivery of more mineral material). At the end of Atlantic (5600 \pm 70 14C yr BP), the Yaselda riverbed moved to the south, forming an oxbow lake, which is still connected with the Yaselda active riverbed.

\section{METHODS}

This publication provides new field data and mainly field observations. Sediment samples taken at different points in the Kokoritsa microregion are currently being processed in the laboratory. During the field work, drilling was carried out using a hand drill, and outcrops were dug with the sediment sampling. The article also presents new data from palynological studies of the Cerealia cultural pollen from the Sporovo II profile and new cartographic material. However, in general, methods such as spore-pollen analysis, radiocarbon analysis, OSL and TL dating, sedimentological analysis, carpological analysis, cartographic method and archaeological excavations are used in our study of the Kokoritsa microregion. The photos presented in this article were taken by D. Tsvirko and M. Kryvaltsevich.

\section{RESULTS}

Drilling of geological boreholes and sampling of sediments were carried out at several points within the Kokoritsa microregion: КАК-5 (or "Кокорица-5"; 52²3'14.82"N

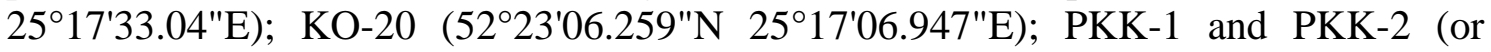
"ПКК-1" and "ПКК-2"; 52॰23'38.448"N 25¹7'35.545"Е); КV-11 (or “Квадрат-11"; approx. 52²3'37.56"N 25¹7'35.39"E) (Fig. 2).

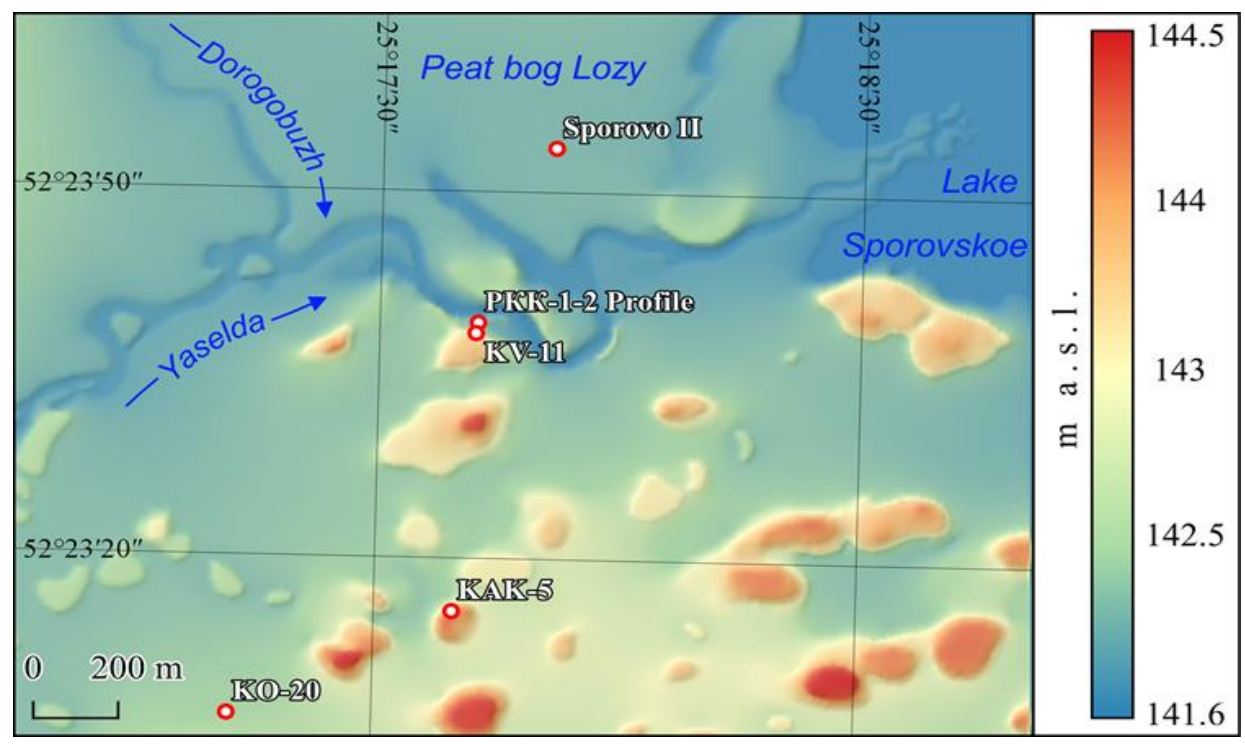

Figure 2. The investigated site with study points on a fragment of the digital elevation model (DEM) based on aerial photography materials [4] 
The field description of the sandy elevation deposits from the KAK-5 profile is given in Table 1. The KAK-5 profile was made from the wall of the ditch located on a sandy hill (Fig. 3). The upper part of the black sands with humus was destroyed by human activities. Sediment samples were taken for sedimentological analysis and OSL dating.

The main feature of the KAK-5 profile is the presence of horizontal bedding of the sediments. In the middle and lower parts of the KAK-5 profile, where the deposits are not disturbed by human agricultural activities, there is an alternation of coarse sands with medium and fine sands, as well as with silts (Fig. 4).

Table 1. Field description of the KAK-5 sediment column

\begin{tabular}{|l|l|l|l|}
\hline KAK-5 & Depth, cm & Lithology, field description \\
\hline Depth, cm & Lithology, field description & $114-117$ & silts, greenish-white \\
\hline $13-13$ & medium sands, with humus, black & $117-123$ & medium sands, yellow \\
\hline $37-49$ & fine sands, yellow & $123-125$ & coarse sands, yellow \\
\hline $49-54$ & $\begin{array}{l}\text { fine sands, horizontally layered, yellow sands, horizontally layered, } \\
\text { yellow }\end{array}$ & $125-133$ & $\begin{array}{l}\text { fine-medium-grained sands, } \\
\text { yellow }\end{array}$ \\
\hline $54-60$ & fine sands, horizontally layered, yellow & $133-138$ & coarse sands \\
\hline $60-62$ & medium sands, yellow & $138-172$ & fine sands \\
\hline $62-68$ & $\begin{array}{l}\text { fine-medium-grained sands, horizontally } \\
\text { layered, yellow }\end{array}$ & $172-175$ & medium sands \\
\hline $68-74$ & fine sands, horizontally layered, yellow & $175-177$ & coarse sands \\
\hline $74-98$ & $\begin{array}{l}\text { fine-medium-grained sands, horizontally } \\
\text { layered, yellow }\end{array}$ & $177-189$ & medium sands \\
\hline $98-101$ & coarse sands, yellow & $189-190$ & coarse sands \\
\hline $101-105$ & fine sands & $190-193$ & silts \\
\hline $105-108$ & silts, greenish & $214-214$ & fine-medium-grained sands \\
\hline $108-113$ & fine sands, white & $215-220$ & coarse sands \\
\hline $113-114$ & coarse sands & fine sands-silts \\
\hline
\end{tabular}

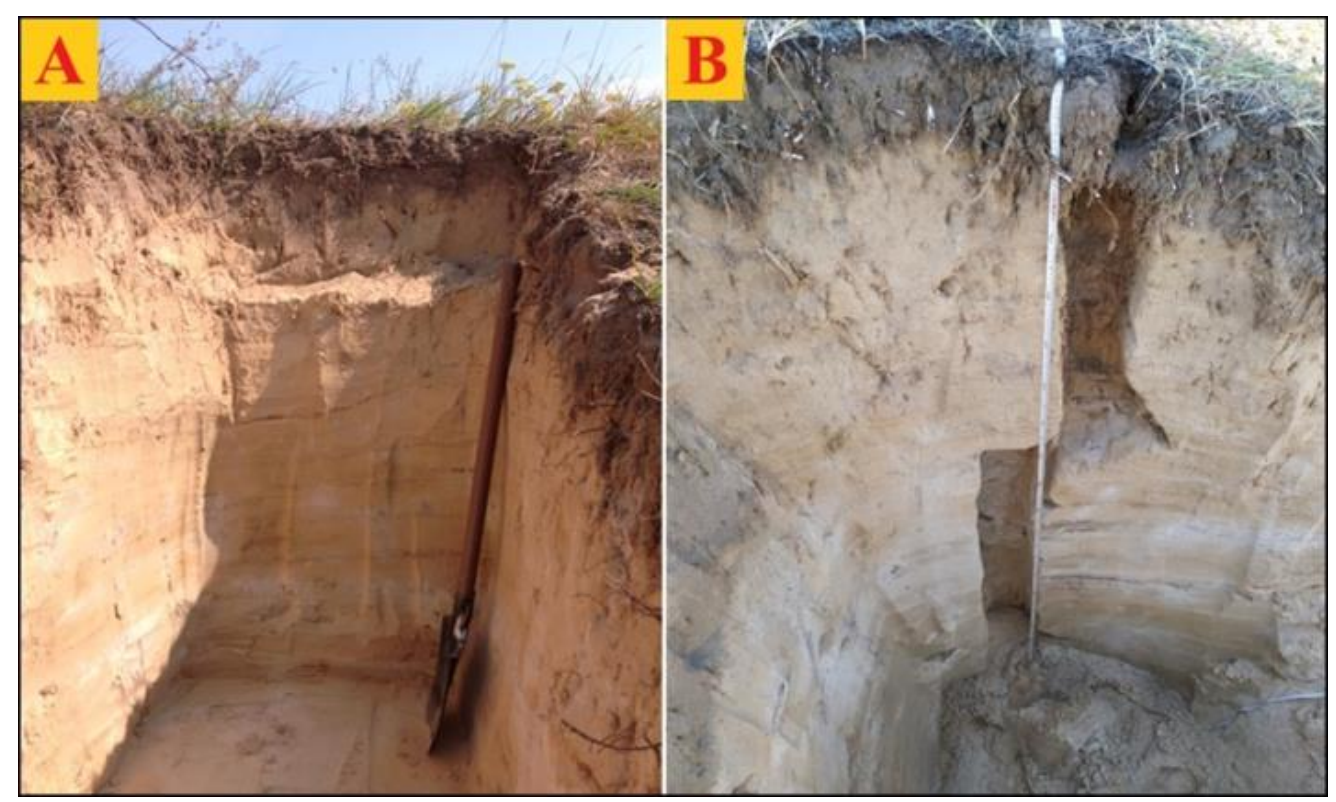

Figure 3. Deposits of the KAK-5 profile. A - before sampling; B - after sampling. Sampling was carried out from the wall against which the shovel was leaning 


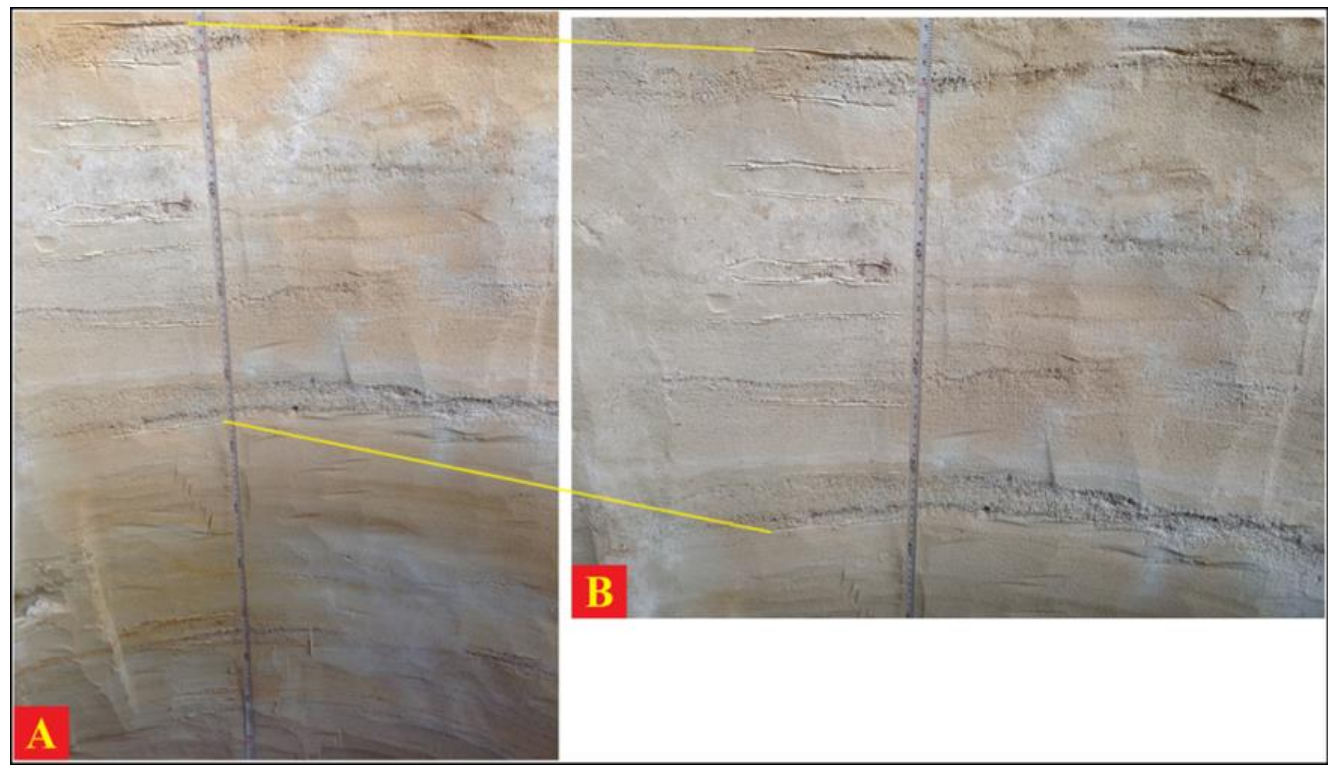

Figure 4. A-B - Horizontal bedding of the KAK-5 profile sediments

Table 2 shows the results of drilling of bog deposits at point KO-20 with a field description of the sediments. The peat bog massif, inside which the KO-20 point is located, is very expressive in the relief as a flat area overgrown with tall herbaceous vegetation. The relief of the bog is more clearly visible from the hill on which the KAK5 point is situated (Fig. 5). The samples from KO-20 will be used for sedimentological analysis and radiocarbon dating (Fig. 6).

Table 2. Field description of the KO-20 sediments.

\begin{tabular}{|l|l|l|l|}
\hline KO-20 & \multicolumn{3}{|l|}{} \\
\hline Depth, cm & Lithology, field description & Depth, cm & Lithology, field description \\
\hline $0-11$ & silty peats, brown & $81-146$ & silty peats, brown \\
\hline $11-81$ & silty peats, black & $146-185$ & silts \\
\hline
\end{tabular}

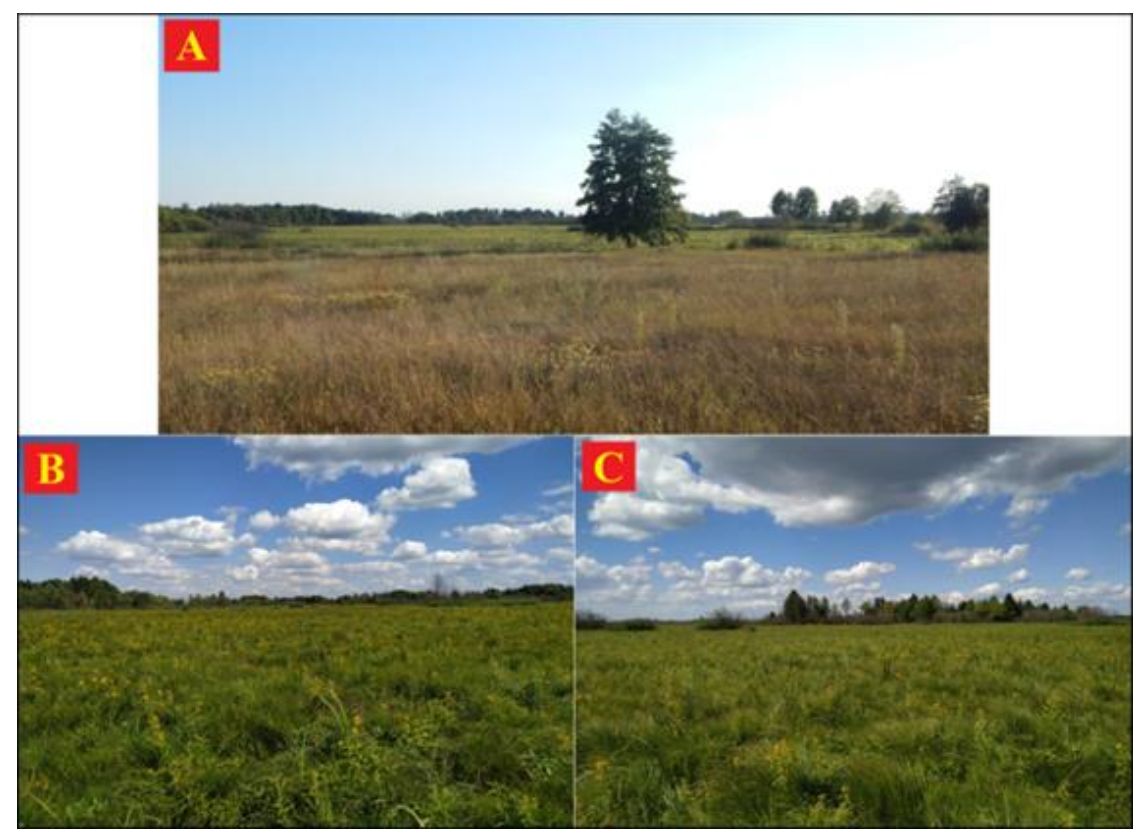

Figure 5. View of the peat bog massif, within which the KO-20 point is located. $\mathrm{A}$ - view from the hill with the point $\mathrm{KAK}-5$; B-C - view of the bog from point KO-20 


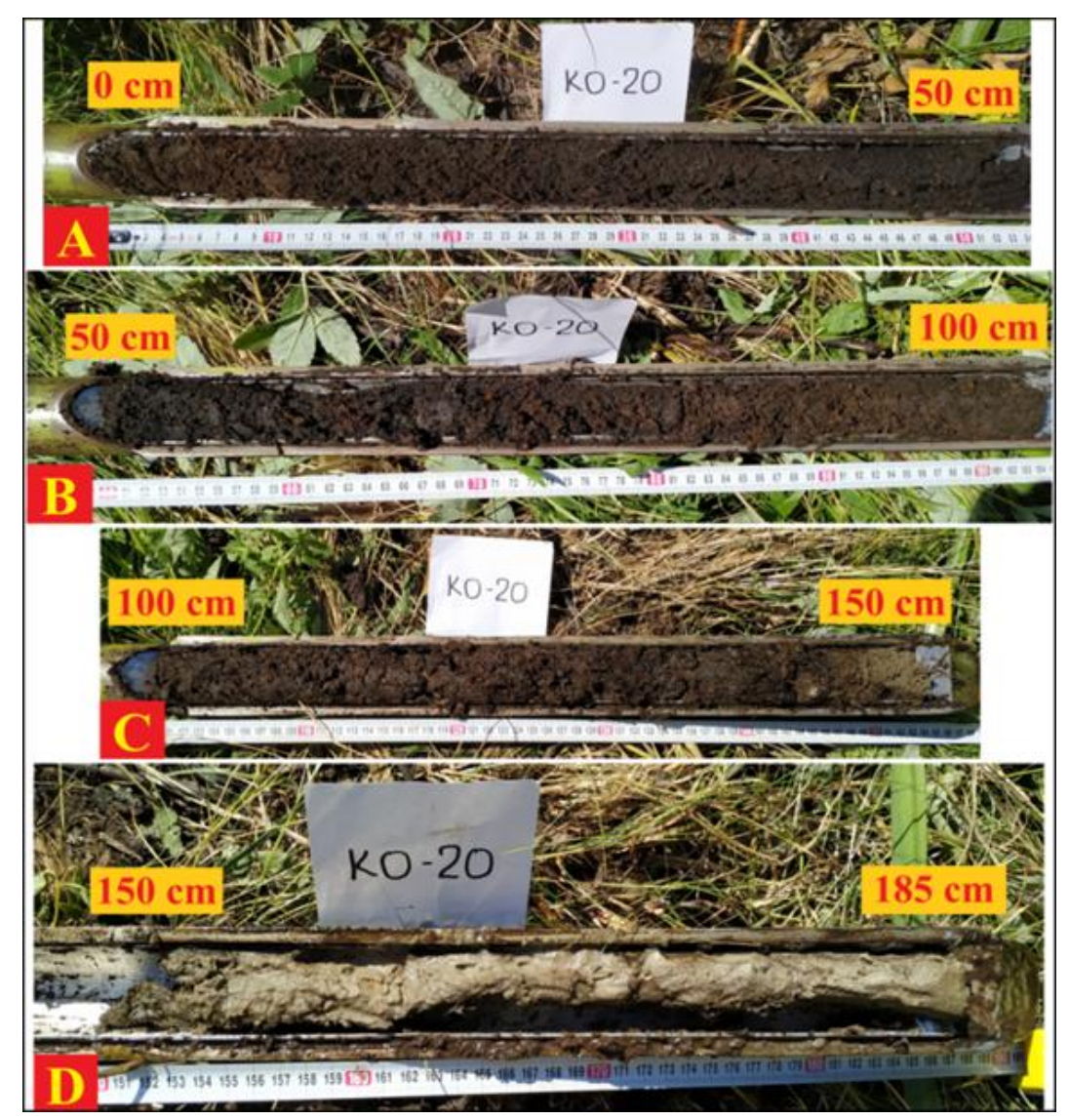

Figure 6. Core of peat deposits (A-C) underlain by silts (C-D), KO-20 profile

Sections PKK-1 and PKK-2 represent one profile (PKK-1-2 Profile), however, for PKK1 the samples were taken with a drill (since the part of PKK-1 deposits is below the groundwater level), and for PKK-2 the samples were taken from the outcrop wall (Fig. 7). The selected samples are in the process of sedimentological, radiocarbon and carpological analyzes. The field description of the deposits of the PKK-1-2 Profile is given in Table 3.

Table 3. Field description of the sediments from PKK-1-2 Profile.

\begin{tabular}{|c|c|c|c|}
\hline \multicolumn{4}{|c|}{ PKK-1-2 Profile (for carpology) } \\
\hline Depth, cm & Lithology, field description & Depth, cm & Lithology, field description \\
\hline \multicolumn{2}{|l|}{ PKK-2 } & \multicolumn{2}{|l|}{ PKK-1 } \\
\hline $0-23$ & highly decomposed peats, brown & $60-110$ & $\begin{array}{l}\text { highly organic peats, brown, } \\
\text { brown-black }\end{array}$ \\
\hline $23-28$ & $\begin{array}{l}\text { highly decomposed peats, sandy, } \\
\text { brown }\end{array}$ & $110-133$ & peats, brown-black \\
\hline $28-33$ & peaty silts with sands, brown-black & $133-150$ & fine-medium-grained sands \\
\hline $33-40$ & peaty silts with sands, black & & \\
\hline $40-49$ & peaty silts, black & & \\
\hline $49-60$ & $\begin{array}{l}\text { highly organic peats, brown, brown- } \\
\text { black }\end{array}$ & & \\
\hline
\end{tabular}




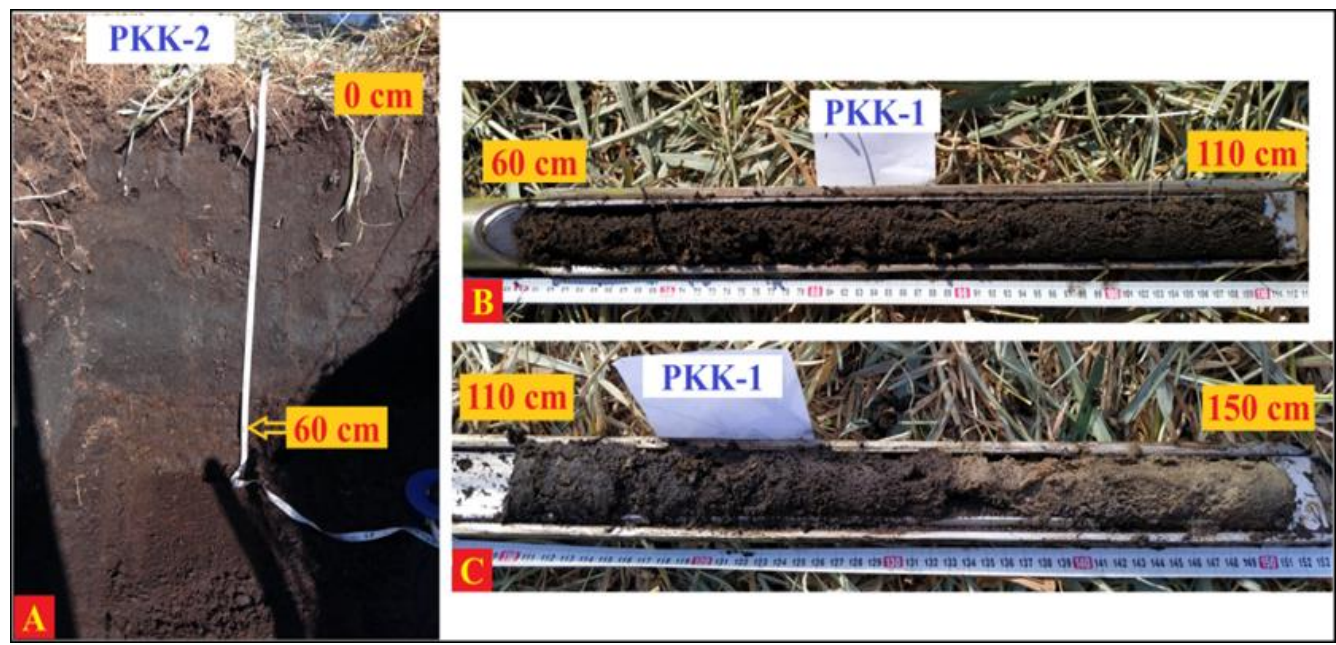

Figure 7. Peat deposits (A-C) of the PKK-1-2 Profile underlain by fine-medium sands (C). A - PKK-2 sediments from the outcrop wall; B-C - PKK-1 sediment core

After macroscopic evaluation of the sediments from the PKK-2 outcrop, a dark layer of peaty silts with an admixture of sands was found, which extends along all the walls of the outcrop (Fig. 8-9). To date this layer 2 samples for radiocarbon analysis were selected from the east wall of the PKK-2 outcrop (from which samples for carpological analysis had been already taken) $-\approx$ above and below the black layer of peaty silts with sands (Fig. 9). One of the most important discoveries from the PKK-1-2 Profile is the finding of the Early Neolithic pottery in the peat deposits of the PKK-2 section (east wall) at a depth of $50 \mathrm{~cm}$ (Fig. 9). The Early Neolithic pottery lies approximately on the border of 2 layers: a brown layer of highly organic peats and a black layer of peaty silts with sands. Another object was found on the south wall of the PKK-2 outcrop - wood in a brown layer of highly organic peats at a depth of approximately $80 \mathrm{~cm}$ (Fig 8).

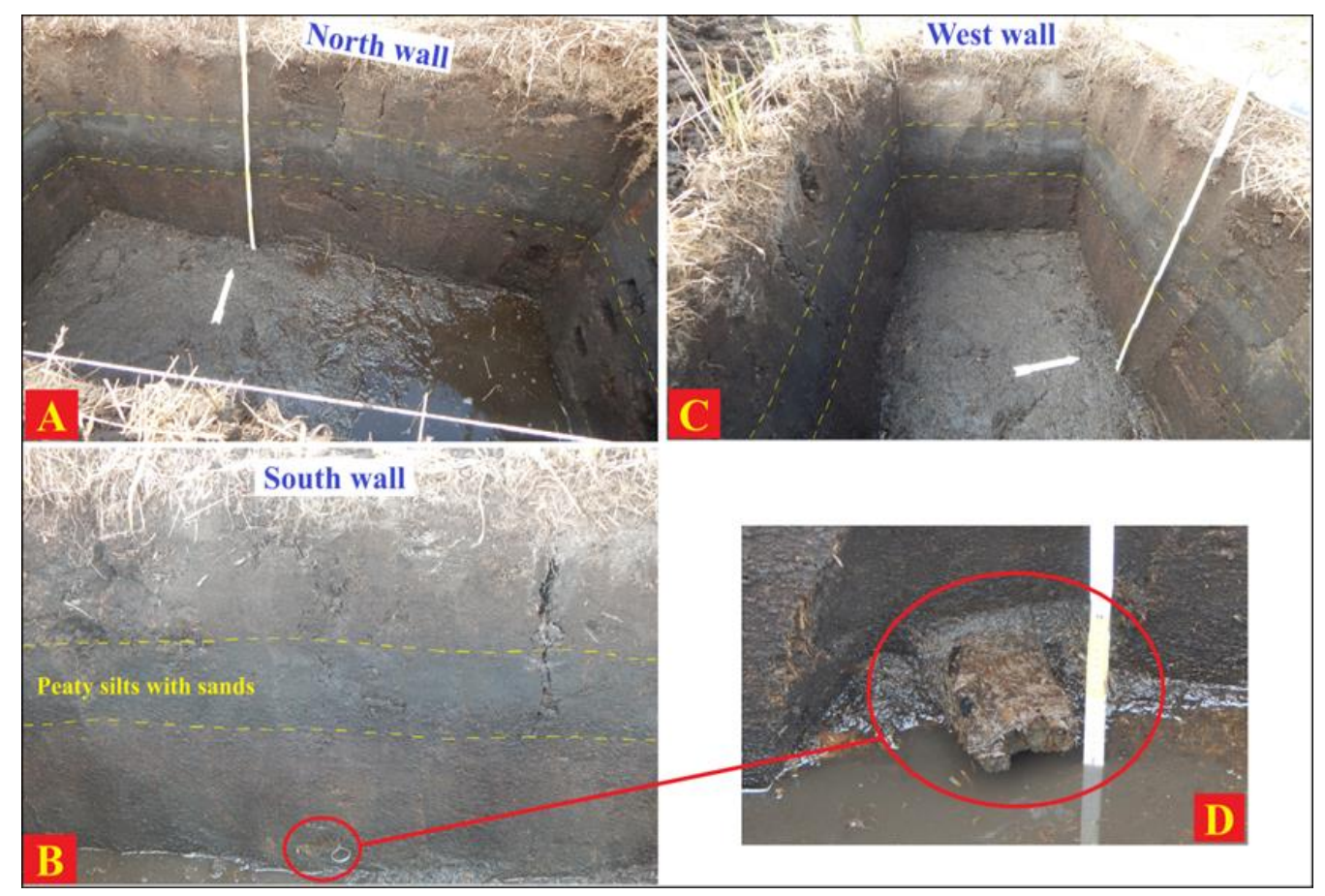

Figure 8. A black layer of peaty silts with sands on the north (A), south (B) and west walls of the PKK-2 outcrop (upper part of the PKK-1-2 Profile). D - buried wood 


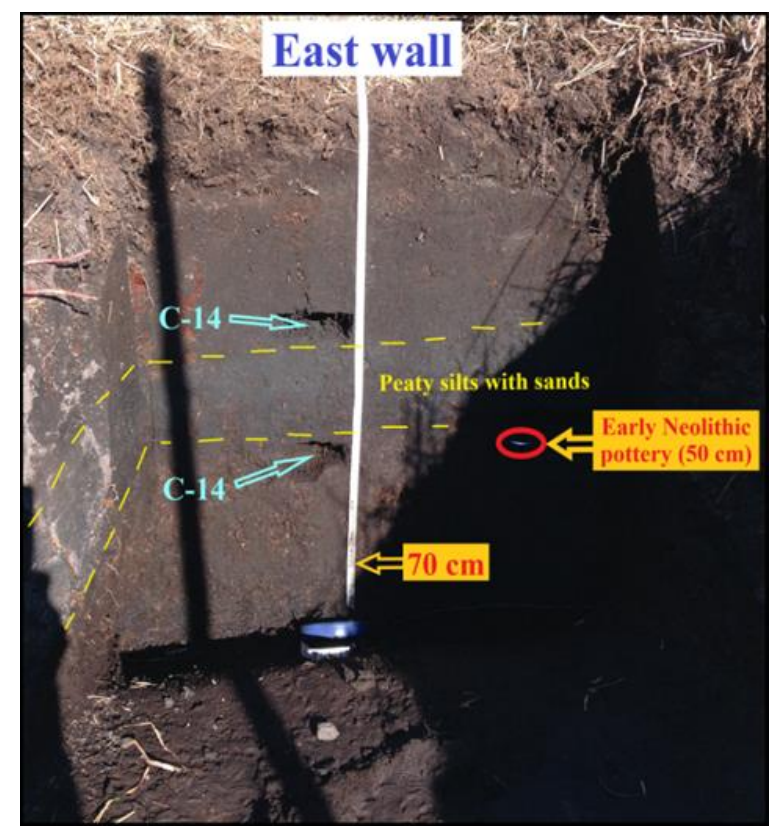

Figure 9. A black layer of peaty silts with sands on the east wall of the PKK-2 outcrop (upper part of the PKK-1-2 Profile). The Early Neolithic pottery in the PKK-2 section

The core of KV-11 sediments was taken from square 11 of the archaeological excavation 2 at the "Kakoryca-4" site and had the following field description presented in Table 4. KV-11 samples were taken for sedimentological analysis, radiocarbon and OSL dating (Fig. 10). From excavation 2 of the archaeological site "Kakoryca-4", 3 samples of pottery were taken along with the surrounding deposits for thermoluminescence (TL) dating (squares 10, 11 and 12).

Table 4. Field description of the KV-11 sediments.

\begin{tabular}{|l|l|}
\hline KV-11 \\
\hline Depth, cm & Lithology, field description \\
\hline $0-27$ & silty peats, black-brown \\
\hline $27-49$ & fine sands, silty, black, sticky \\
\hline $49-95$ & fine sands, organic, gray, gray-white \\
\hline
\end{tabular}

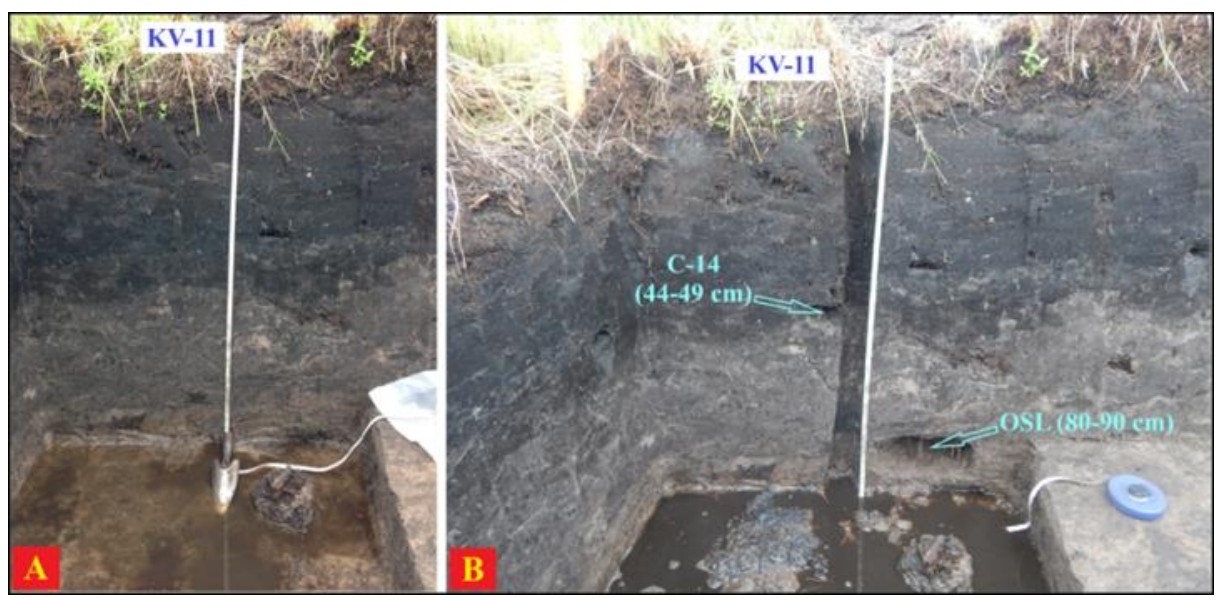

Figure 10. KV-11 deposits from the wall of excavation 2 of the archaeological site "Kakoryca-4": silty peats underlain by fine sands. A-before sampling; B-after sampling Spore-pollen analysis of Sporovo II deposits revealed the presence of Cerealia pollen in several samples at different depths. The oldest pollen grains of Cerealia lay at depths of $145-155 \mathrm{~cm}$ and were dated to approximately $700014 \mathrm{C}$ yr BP (Fig. 11). 


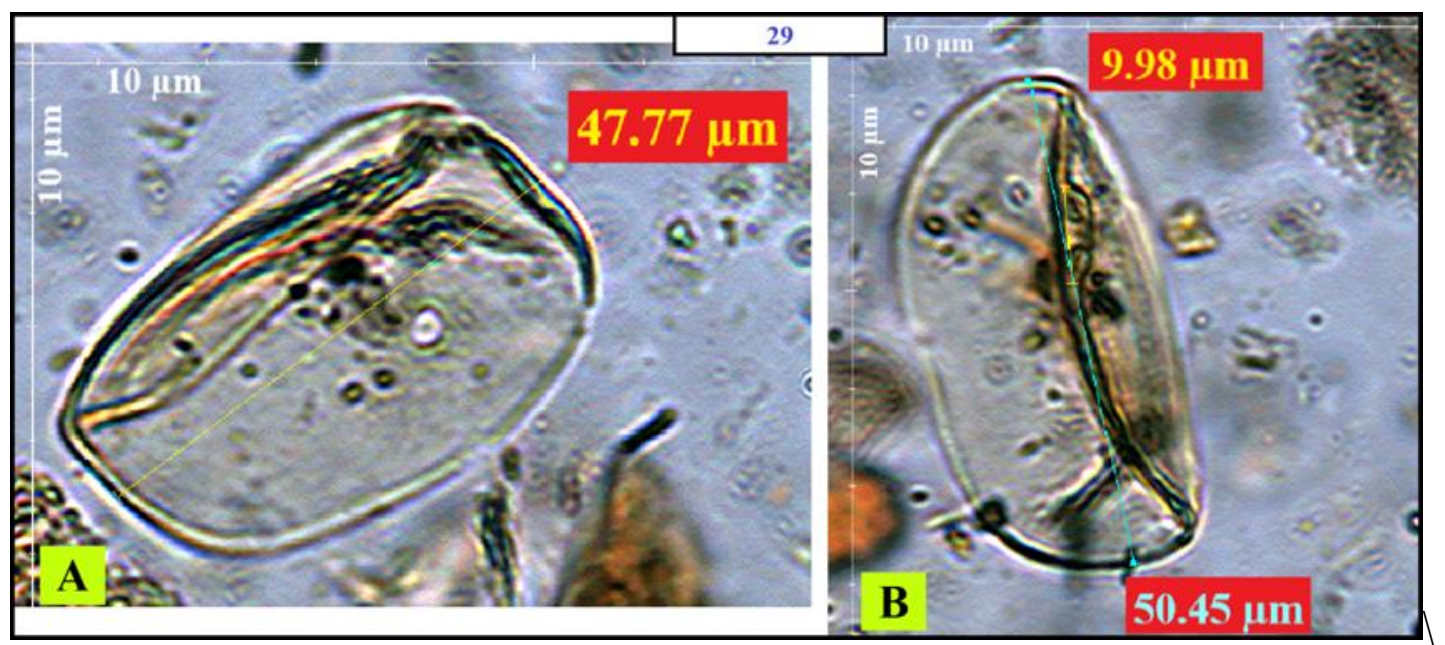

Figure 11. Cerealia pollen grain from a depth of $145-150 \mathrm{~cm}$ in different positions under a light microscope. A - the length of the long axis $(47,77 \mu \mathrm{m}) ; \mathrm{B}-$ the length of the long axis $(50,45 \mu \mathrm{m})$ and diameter of annulus $(9,98 \mu \mathrm{m})$ in a different grain position.

Cerealia pollen was also found at a depth of $95-97 \mathrm{~cm}$, as well as in the uppermost ( $\approx$ subrecent) layer of peat deposits $(0-5 \mathrm{~cm})$ (Fig. 12). The results of measurements under a light microscope of Cerealia pollen grains from Sporovo II profile are presented in Table 5.

Table 5. Results of measurements under a light microscope of the long axis and diameter of annulus of Cerealia pollen grains from Sporovo II profile

\begin{tabular}{|c|c|c|c|c|c|}
\hline \multirow{2}{*}{$\begin{array}{l}\text { Estimated } \\
\text { age }\end{array}$} & \multirow{2}{*}{$\begin{array}{l}\text { Sample } \\
\text { Name } \\
\text { (Depth, cm) }\end{array}$} & \multicolumn{2}{|c|}{$\begin{array}{ll}\text { Long } & \text { axis } \\
\text { (polar diameter), } \mu \mathrm{m} & \\
\end{array}$} & \multicolumn{2}{|c|}{$\begin{array}{l}\text { Diameter of annulus } \\
\text { (ulcus/porus }+ \text { annulus) }, \mu \mathrm{m}\end{array}$} \\
\hline & & Average & All measurements & Average & All measurements \\
\hline $\begin{array}{l}7181^{14} \mathrm{C} \text { yr } \\
\mathrm{BP}(8086 \mathrm{cal} \\
\mathrm{yr} \mathrm{BP})\end{array}$ & $\begin{array}{l}30 \quad(155-150 \\
\mathrm{cm})\end{array}$ & 47,02 & $\begin{array}{lrr}46,05 ; & 46,88 ; & 47,07 ; \\
48,86 ; 50,46 ; 46,13 ; 44,8 ; \\
45,21 ; & 45,22 ; & 44,76 ; \\
50,72 ; & 50,36 ; & 45,65 ; \\
46,13 . & & \\
\end{array}$ & 9,24 & $\begin{array}{l}8,98 ; 8,81 ; 9,62 ; \\
9,83 ; 8,46 ; 9,54 ; \\
9,63 ; 9,5 ; 8,83\end{array}$ \\
\hline $\begin{array}{l}7031{ }^{14} \mathrm{C} \text { yr } \\
\mathrm{BP}(7924 \mathrm{cal} \\
\mathrm{yr} \mathrm{BP})\end{array}$ & $\begin{array}{l}29(150-145 \\
\mathrm{cm})\end{array}$ & 49,83 & $\begin{array}{lll}47,51 ; & 47,77 ; & 50,98 ; \\
51,63 ; & 50,94 ; & 50,45 ; \\
49,52 . & & \\
\end{array}$ & 9,96 & $\begin{array}{l}\text { 10,64; 9,98; 9,89; } \\
9,85 ; 9,67 ; 9,68 ; \\
9,98 .\end{array}$ \\
\hline \multirow{2}{*}{$\begin{array}{l}\approx 5600{ }^{14} \mathrm{C} \text { yr } \\
\mathrm{BP}(6391 \mathrm{cal} \\
\mathrm{yr} \mathrm{BP})\end{array}$} & $\begin{array}{l}\text { B19 } \\
\mathrm{cm})\end{array}$ & 49,73 & $\begin{array}{lcc}49,94 ; & 49,77 ; & 49,81 ; \\
50,06 ; 50,12 ; 50 ; & 49,54 ; \\
49,09 ; \quad 49,83 ; & 50,06 ; \\
49,88 ; 49,81 ; 48,57\end{array}$ & 8,93 & $\begin{array}{l}9,08 ; 8,91 ; 8,97 ; \\
8,91 ; 8,7 ; \quad 8,65 \\
9,06 ; 9,08 ; 9,04\end{array}$ \\
\hline & $\begin{array}{l}\text { B19 }(\mathrm{Re}- \\
\text { measurement })\end{array}$ & 49,73 & $\begin{array}{l}49,49 ; 49,72 ; 49,95 ; 50 ; \\
50,46 ; 50,1 ; 49,26 ; 49,64 ; \\
49,72 ; 50,01 ; 48,67\end{array}$ & 9,01 & $\begin{array}{lll}9,05 ; & 8,83 ; 8,83 ; \\
9,14 ; 8,67 ; & 9,38 ; \\
9,16 . & & \\
\end{array}$ \\
\hline $\begin{array}{l}\text { End of the } \\
\text { Subatlantic } \\
(\approx \text { subrecent })\end{array}$ & $1(5-0 \mathrm{~cm})$ & 46,57 & 46,$41 ; 46,56 ; 46,73$ & 9,68 & $\begin{array}{l}8,85 ; 8,99 ; 10,95 ; \\
9,92 .\end{array}$ \\
\hline
\end{tabular}




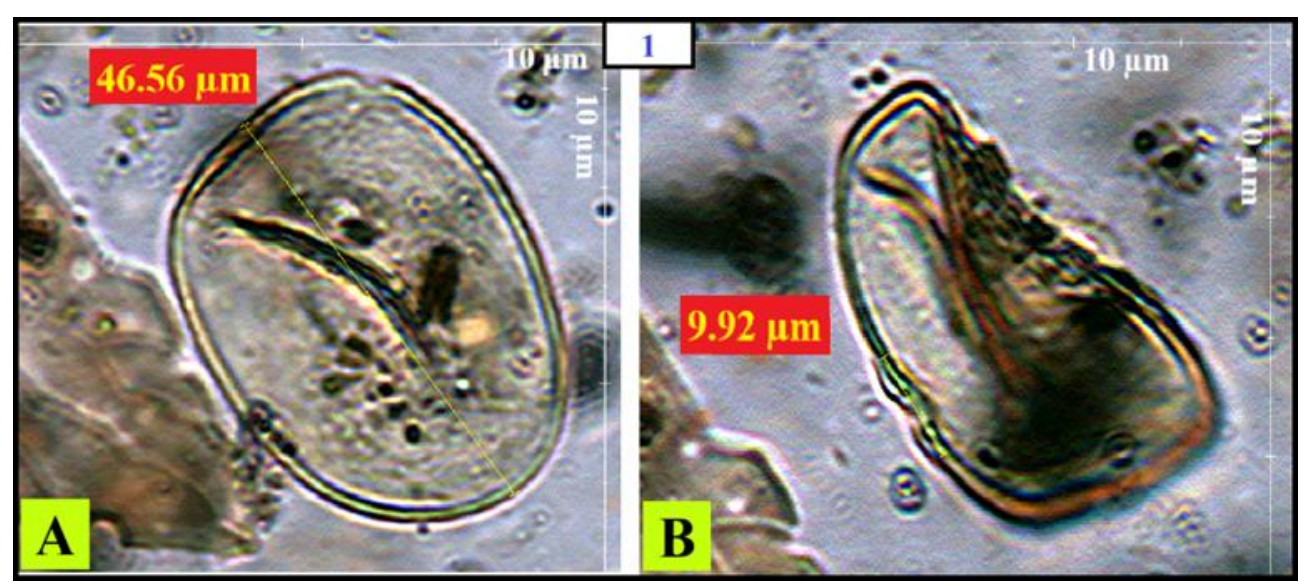

Figure 12. Cerealia pollen grain from a depth of $0-5 \mathrm{~cm}$ in different positions under a light microscope. A - the length of the long axis $(46,56 \mu \mathrm{m})$; B - diameter of annulus $(9,92 \mu \mathrm{m})$ in a different grain position

\section{DISCUSSION AND PRELIMINARY CONCLUSIONS}

The field observations obtained during the 2020 expedition to the Kokoritsa microregion and samples taken for laboratory analyses complement the general picture of the development of the natural environment of this territory.

As a result of field studies, some conclusions were made about the features of the processes that formed the sandy elevations, one of which is the archaeological site "Kakoryca-4". Based on the lithological structure (which was revealed at the KAK-5 profile) of one of these sandy hills it can be assumed that the horizontal bedding of coarsemedium-fine sands and silts indicates the accumulation of these deposits by a braided river with small dynamic triggered by the very small slope of the river. In Belarusian literature and on geological maps with the Kokoritsa microregion, these deposits from the sandy elevations are called "limno-alluvial" [5].

The time of formation of the black layer of peaty silts with sands in the PKK-2 section, which extends along all the walls of the PKK-2 outcrop, is of considerable interest. We assume that between $700014 \mathrm{C}$ yr BP and 5600 14C yr BP, the Yaselda riverbed was closer to the Sporovo II profile, which led to the accumulation of silty peats in it. Then, about $5600 \pm 7014 \mathrm{C}$ yr BP (when at point Sporovo II the accumulation of silty peats stopped), an increase in fluvial activity took place and the Yaselda riverbed laterally migrated to the south, forming an oxbow lake. This change in the position of the riverbed occurred during the phase of an increase fluvial dynamic known from other Belarusian river valleys [6]. Increased fluvial activity and a change in the position of the Yaselda riverbed (the Yaselda river became closer to the PKK-2 point) led to the beginning of the accumulation of the layer of peaty silts with sands in the PKK-2 outcrop. Accordingly, we presume that the black layer of peaty silts with sands in the PKK-2 section began to accumulate tentatively around $5600 \pm 7014 \mathrm{C}$ yr BP (the approximate beginning of the period of increased fluvial activity of Yaselda). The Early Neolithic pottery found at the boundary of the layers (a black layer of peaty silts with sands and a brown layer of highly organic peats) does not contradict the date 5600 $\pm 7014 \mathrm{C}$ yr BP and may correspond to it. The obtained spore-pollen materials, in particular, the Cerealia pollen data, allow us to make the assumption-reconstruction of 7000 BP old vegetation (Fig. 13). It is assumed that at that time on the territory of the Kokoritsa microregion there was an early form of agriculture, or there was a wild form of Cerealia. Probably single Cerealia could grow near dwellings or temporary sites of prehistoric people. These prehistoric settlement sites 
were located on elevated places (on sandy hills), from which the Cerealia pollen was probably carried by the wind and deposited on the surrounding peat bogs.

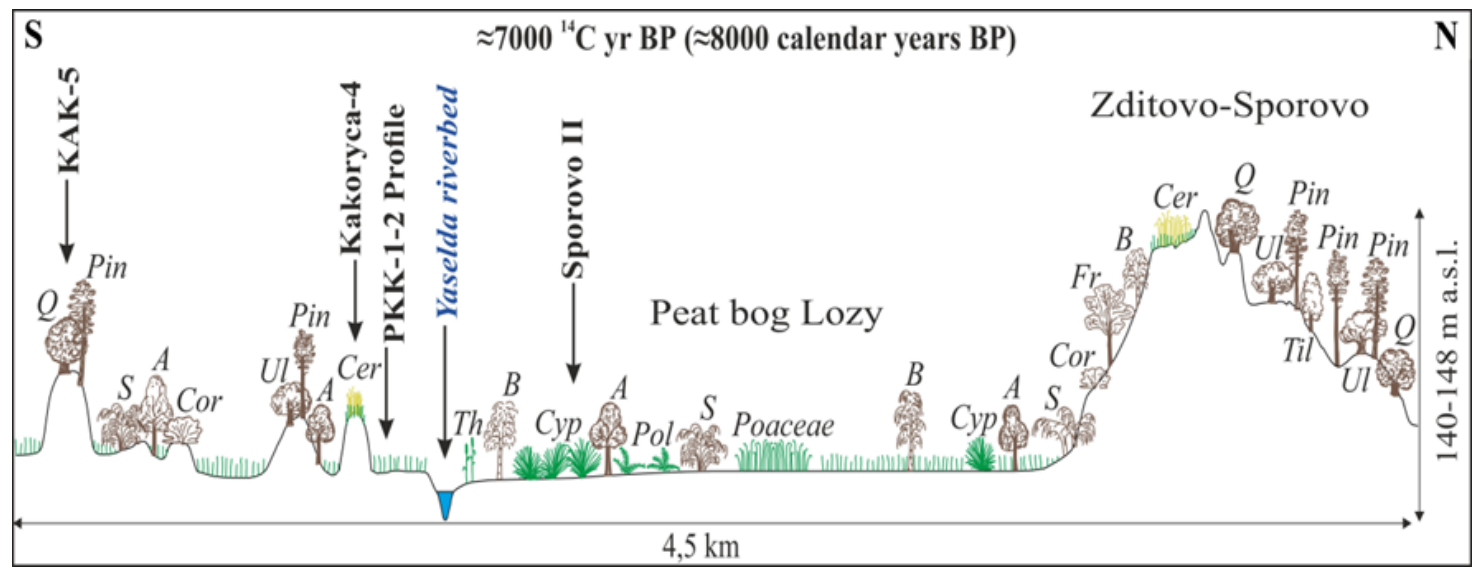

Figure 13. Reconstruction of the composition of vegetation on the territory of the Kokoritsa microregion 7000 BP (8000 cal yr BP) based on spore-pollen analysis. Pin - Pinus; Q - Quercus; Ul - Ulmus; Til Tilia; Fr - Fraxinus; B - Betula; A - Alnus; Cor - Corylus; S - Salix; Cyp - Cyperaceae; Cer - Cerealia; Th - Typha; Pol - Polypodiaceae [3].

\section{REFERENCES}

[1] Tsvirko D., Kryvaltsevich M., Tkachou A., Trifonov Y., Kalicki T., Frączek M. \& Kusztal P. Late Glacial and Holocene evolution of landscapes on the territory of Sporovsky Reserve (Belarusian Polesie), Geobalcanica, North Macedonia, 2021, pp 93-100.

[2] Tsvirko D., Kryvaltsevich M., Tkachou A., Trifonov Y., Kalicki T., Frączek M. \& Kusztal P. Late Glacial and Holocene environmental changes on the territory of Sporovsky Reserve (Belarusian Polesie), 25th Quaternary Conference Kvarter, Czech Republic, 2019, p 63.

[3] Trifonov Y., Kryvaltsevich M., Tkachou A. \& Tsvirko D. Kakoryca-4 - a new monument of the Stone and Bronze Ages. The first results of a comprehensive study, Muzeynyya zdabytki, Belarus, 2020, pp 42-52 (in Belarusian).

[4] The case for the formation of digital orthophotomaps at the object Б.12.0585.7 (Drogichinsky district) Brest region. Contract №7-4, State enterprise «БелПСХАГИ», Priluki, 26 p, 2017 (in Russian).

[5] State geological map (map of Quaternary deposits), 1:200 000, N-35-XXXII (Drogichin), USSR Ministry of Geology, Leningrad, 1982 (in Russian).

[6] Kalicki, T. Zapis zmian klimatu oraz działalności człowieka i ich rola w holoceńskiej ewolucji dolin środkowoeuropejskich, Warszawa, PAN IGiPZ, 348 p, 2006 